\title{
PERAN PEKERJA SOSIAL di BIDANG INDUSTRI pada PASAR BEBAS ASEAN di INDONESIA
}

\author{
Oleh: \\ Sunny Aqilah Qurani, Ishartono, \& Gigin G. K.Basar \\ E-mail : \\ sunnyqurani@gmail.com
}

\begin{abstract}
ABSTRAK, Pasar bebas ASEAN membuat perusahaan-perusahaan nasional dan internasional dapat mendirikan perusahaannya dengan lebih bebas di Indonesia. Selain itu, jangkauan pasar perusahaanperusahaan yang berada di kawasan ASEAN juga semakin luas. Hal ini menyebabkan kompetensi antar satu perusahaan dengan perusahaan lainnya semakin tinggi, baik dalam bentuk produk maupun jasa. Produk dan jasa yang berkualitas dapat diciptakan jika sumber daya manusianya (karyawan di dalam perusahaan) dapat menjalankan pekerjaannya dengan nyaman dan tanpa hambatan. Faktor internal dan eksternal perusahaan menjadi penyebab terjadinya hambatan dan tekanan bagi karyawan yang berdampak terhadap menurunnya kualitas kerja karyawan. Pekerja sosial industri dapat menjadi salah satu profesi yang ada di dalam perusahaan yang bekerja untuk meningkatkan produktifitas kerja karyawan melalui metode-metode yang dimilikinya. Pembahasan dari artikel ini menjelaskan tentang peran pekerja sosial di dalam perusahaan untuk meningkatkan produktifitas karyawan dengan memperhatikan hambatan-hambatan yang dapat menurunkan kinerja karyawan dalam bekerja. Pekerja sosial di bidang industri juga bekerja untuk menjalin hubungan baik antar perusahaan dengan mayarakat setempat sebagai bentuk dari tanggungjawab sosial perusahaan.
\end{abstract}

Kata Kunci : pekerja sosial, perusahaan, karyawan, masyarakat

Abstract, ASEAN free market making firms can establish a national and international company with more freedom in Indonesia. In addition, the market reach the companies that are in the ASEAN region is also increasingly widespread. This leads to competence between one company with another company higher, either in the form of products and services. Quality products and services that could be created if its human resources (employees in the company) can carry out its work comfortably and without barriers. Internal and external factors cause the occurrence of obstacles and pressures for employees who have an impact on the declining quality of work of employees. The social worker industry can become one of the professions that exist in the company are working to improve employee productivity through its methods. Discussion of this article describes the role of social workers in the enterprise to improve employee productivity by taking into account the constraints that may degrade the performance of employees in the work. The social worker in the industrial sector also works for harmonic relationship between companies with the local society as a form of corporate social responsibility.

Keywords: social workers, companies, employees, society 


\section{PENDAHULUAN}

Indonesia merupakan salah satu Negara ASEAN yang menjadi anggota dari pasar bebas ASEAN yang akan diselenggarakan pada tahun 2015. Pasar bebas ASEAN yang dimaksud adalah pasar tunggal dan berbasis produksi tunggal. Di dalamnya terjadi arus barang, jasa, investasi, dan tenaga terampil serta arus modal yang lebih bebas diantara Negara ASEAN pada akhir 2015 mendatang. Arus ekspor-impor barang dan jasa maupun investasi antar negara ASEAN akan lebih terbuka, sedangkan tarif dan nontarif sudah tidak diberlakukan lagi. Tujuan dari adanya pasar bebas adalah meluaskan pangsa dan jangkauan pasar pada skala ASEAN dan juga global, sehingga nantinya diharapkan akan berpengaruh terhadap penambahan pendapatan dan pertumbuhan ekonomi serta ketertarikan Negara luar untuk berinvestasi dan mendirikan perusahaan di Negara-negara ASEAN.

Pada setiap Negara yang tergabung dalam pasar bebas ASEAN, masing-masing anggota masyarakatnya dibolehkan untuk mendirikan perusahaan di Negara lain dan atau bekerja di Negara lain dengan lebih bebas. Tidak terkecuali dengan di Indonesia, masyarakat dari Negara lain juga akan turut mendirikan perusahaan dan juga bersaing dengan masyarakat lokal untuk mendapatkan pekerjaan. Negara Indonesia akan banyak ditempati oleh perusahaan-perusahaan, baik perusahaan yang diciptakan oleh masyarakat lokal Indonesia maupun perusahaan yang berasal dari luar negeri. Sumber daya manusia yang banyak serta sumber daya alam yang berlimpah membuat Indonesia menjadi daya tarik bagi para penanam modal dari Negara luar untuk mendirikan perusahaannya di Indonesia. Berbagai macam posisi di dalam perusahaan juga semakin beragam dan membuka lowongan pekerjaan baik bagi masyarakat lokal maupun masyarakat luar. Salah satu pekerjaan yang berpeluang di Indonesia pada pasar bebas ASEAN adalah pekerja sosial di bidang industri. Pekerja sosial merupakan profesi yang bertujuan untuk meningkatkan keberfungsian sosial individu, kelompok, komunitas dan masyarakat dengan memperhatikan kondisi biopsikososial individu di dalamnya.

Perusahaan-perusahaan di dunia pada masa kini tidak hanya mengandalkan kerja mesin untuk menghasilkan produk yang berkualitas, tetapi lebih mengandalkan sumber daya manusia yang merupakan subyek dalam melakukan pekerjaan. Sudah banyak perusahaan yang menyadari betul pengaruh kualitas sumber daya manusia terhadap kualitas produk maupun jasa yang dihasilkan untuk dinikmati konsumen. Masalah-masalah yang dihadapi oleh karyawan di luar perusahaan, seperti masalah dalam pernikahan, kecanduan narkoba, depresi, dan lain sebagainya berpengaruh terhadap efektifitas kerja karyawan. Oleh karena itu dibutuhkan suatu pemberian pertolongan terhadap masalah-masalah yang dihadapi oleh karyawan. Penyelesaian masalah dari karyawan di dalam suatu perusahaan tidak hanya bersifat sementara dan isidental, melainkan harus terus berkelanjutan serta turut memperhatikan kondisi biopsikososial dari karyawan. Pekerja sosial dapat bekerja dalam industri atau perusahaan untuk membantu karyawannya menemukan pemecahan masalah yang dihadapi serta akses kepada sumbersumber yang diperlukan baik dalam tingkat individu, kelompok, lembaga atau masyarakat. Pekerja sosial juga dapat membantu manajer perusahaan untuk menggali potensi dan masalah karyawan yang kemudian dapat dijadikan landasan untuk pemberian pelatihan atau pendidikan yang berguna untuk peningkatan kualitas sumber daya manusia pada jangka panjang. Selain itu, pekerja sosial industri juga bekerja pada bagian eksternal perusahaan, dimana pekerja sosial mengurusi hubungan perusahaan dengan masyarakat agar tercipta jalinan yang baik antar kedua belah pihak.

Perusahaan-perusahaan besar yang berada di Eropa dan Amerika sudah banyak 
yang menyediakan pelayanan untuk membantu menyelesaikan masalah karyawannya dari beberapa puluh tahun yang lalu, seperti contoh perusahaan yang disebutkan Jorgensen dalam Social Work in Business and Industry yang mempekerjakan pekerja sosial di dalam perusahaannya untuk memberikan pelayanan bagi karyawan-karyawannya yang memiliki masalah, yaitu :

1) Sebuah perusahaan angkutan kota New York telah menyediakan pelayanan bagi pekerja alkoholik dengan waktu hampir 20 tahun lamanya.

2) Program U.S Steel di Chicago yang memiliki 11.000 pekerja dan termasuk kegiatan preventif, pelayanan langsung, konsultasi dan pelatihan-pelatihan.

3) Sebuah bank besar di Tucson, Arizona, dengan 6.000 pekerja dan sebuah pabrik elektronik di Phoenix dengan 5.000 pekerja telah menyediakan pekerja sosial bagi mereka yang masih berada pada standar minimum.

4) Polaroid Coorporation di Boston telah mengupayakan pelayanan pekerjaan sosial bagi para pekerja sosial bagi para pekerjanya, termasuk departemen konseling, yang dimulai pada tahun 1958 dengan sebuah konsultan pekerjaan sosial dengan kerja paruh waktu, saat ini terdapat sejumlah pekerja sosial full time dengan gelar MSW yang melayani hampir 12.000 pekerja, termasuk para manajer dan karyawan tingkat menengah.

5) Lebih dari 7.300 pekerja dari Utah Cooper Division, Kennecott Cooperation, yang dilayani oleh suatu program pekerjaan sosial dengan sebutan INSIGHT. Program ini membantu pekerja dan tanggungannya. Dalam sepuluh tahun, kegiatan ini telah dinikamti oleh lebih dari 5.500 orang, terdiri dari setengahnya merupakan pekerja dan setengahnya adalah tanggungannya. Pemasalahannya terdiri dari permasalahan keluarga, alkoholik, pelanggaran hukum, pernikahan, keuangan, dan masalah obat-obat terlarang.

(http://kesos.unpad.ac.id/?p=480

Diakses 09 Mei 2015 pukul 21:14)

Di AS, pekerja sosial industri pada mulanya dipekerjakan pada pabrik-pabrik tekstil di bagian selatan, di perusahaan International Harvester dan National Cash Register. Mereka melakukan dan atau mengorganisir beragam pelayanan sosial yang meliputi pendirian kamar-kamar istirahat dan kebersihan, perbaikan sanitasi, penyediaan tenaga medis, serta penyediaan makanan, perumahan dan sekolah. Mereka juga mengatur programprogram jaminan sosial dan keamanan, pengadaan perpustakaan, kursus menjahit dan memasak, dan pertolongan pertama pada kecelakaan (PPPK). Bahkan tercatat seorang pekerja sosial yang merancang kolam renang bagi karyawan dan mengusulkan perubahan jadwal Kereta Api agar sesuai dengan para pekerja penglaju (commuter) dari luar kota. Kegiatan-kegiatan tersebut kemudian semakin terintegrasi dengan tugas-tugas para spesialis seperti perawat, petugas kekaryawanan dan administrasi. (http://www.policy.hu/ suharto/ modul_a/makindo_26.htm diakses 09 Mei 2015 pukul 20.54 WIB)

Dari contoh diatas menunjukkan bahwa perusahaan-perusahaan besar di Eropa dan Amerika sudah menyediakan pelayanan bagi para karyawan dengan menggunakan pekerja sosial sebagai pihak yang melaksanakan intervensi di dalamnya. Pelayanan yang disediakan disesuaikan dengan kebutuhan dan masalah yang terjadi pada karyawan-karyawan di dalam perusahaan tersebut. Perusahaan yang sudah mempekerjakan pekerja sosial menyadari bahwa pelayanan yang optimal yang disediakan untuk karyawannya untuk memenuhi kebutuhan dan membantu menyelesaikan masalah, akan berdampak positif bagi karyawan dan perusahaan baik dalam jangka pendek maupun jangka panjang.

Pelayanan yang diberikan oleh perusahaan terhadap karyawannya juga 
seharusnya menjadi perhatian bagi perusahaan-perusahaan nasional maupun internasional yang berdiri di kawasan ASEAN. Hal ini dikarenakan pasar bebas akan menuntut persaingan yang semakin ketat diantara perusahaan-perusahaan di kawasan ASEAN. Persaingan ketat ini kemudian menuntut setiap perusahaan untuk menciptakan produk maupun jasa yang berkualitas tinggi dan dapat diterima oleh pasar internasional. Produk maupun jasa yang berkualitas tinggi dapat diciptakan salah satunya dikarenakan sumber daya manusianya yang juga turut berkualitas. Sumber daya yang berkualitas meliputi didalamnya kondisi biologis, psikologis dan sosialnya yang baik dan juga dapat berfungsi sesuai dengan perannya, baik di dalam lingkungan perusahaan maupun lingkungan luar perusahaan.

Indonesia pada tahun 2015 memiliki jumlah penduduk usia produktif yang banyak. Hal ini menunjukkan bahwa Indonesia pada tahun 2015 mendapatkan bonus demografi, yang kemudian dapat dimanfaatkan untuk meningkatkan perekonomian dan kesejahteraan masyarakat Indonesia. Menurut Head of Economic Analysis Unit Research and Development Division Bursa Efek Indonesia, Musa Haidir, penduduk usia produktif Indonesia 15-29 tahun mencapai 62 juta orang.

(http://www.beritasatu.com/ekonomi/24825560-juta-penduduk-usia-produktif-jadi-modalindonesia.html diakses 10 Mei 2015)

Angka ini dapat 'dimanfaatkan' perusahaan yang berdiri di Indonesia untuk meningkatkan kualitas produk maupun jasa yang dihasilkannya dengan merekrut tenaga terampil yang berada pada usia produktif. Tenaga terampil yang masih berada pada usia produktif memiliki jangka waktu bekerja yang masih lama dibandingkan dengan tenaga terampil yang sudah berada pada usia yang tidak produktif lagi. Tenaga dan fikiran tenaga terampil yang ada pada usia produktif juga masih optimal dan dapat digunakan dengan baik dibandingkan dengan yang sudah berada pada usia tua. Kelebihan ini harus diolah dengan baik oleh perusahaan agar dapat meningkatkan aspek finansial dan juga menjalin hubungan baik dengan karyawan. Metode yang dapat dilakukan adalah melalui pelayanan yang menggunakan intervensi pekerja sosial.

\section{PEMBAHASAN}

Pekerjaan sosial industri dapat didefinisikan sebagai lapangan praktik pekerjaan sosial yang secara khusus menangani kebutuhankebutuhan kemanusiaan dan sosial di dunia kerja melalui berbagai intervensi dan penerapan metoda pertolongan yang bertujuan untuk memelihara adaptasi optimal antara individu dan lingkungannya, terutama lingkungan kerja. Dalam konteks ini, pekerja sosial dapat menangani barbagai kebutuhan individu dan keluarga, relasi dalam perusahaan, serta relasi yang lebih luas antara tempat kerja dan masyarakat (NASW, 1987) atau yang lebih dikenal dengan istilah tanggung jawab perusahaan (corporate social responbility) (suharto, 2006b).

Pekerja sosial dalam ranah dunia industri mempunyai sasaran intervensi terhadap karyawan perusahaan, pemimpin di dalam perusahaan dan juga masyarakat lokal dimana perusahaan berada. Karyawan perusahaan dalam melaksanakan pekerjaannya harus melakukan adaptasi terhadap tugas yang diberikan, lingkungan sosial dan budaya di dalam perusahaan tersebut. Seringkali dalam melakukan adaptasi, karyawan merasa depresi dan tertekan akibat sulitnya menjalin hubungan dengan rekan kerja maupun pimpinan tim. Hal ini menimbulkan turunnya semangat dan kepemilikan terhadap perusahaan dan berdampak pada sulitnya bekerjasama dan mengerjakan tugas yang diberikan. Pergantian tenaga kerja ataupun pemutusan hubungan kerja yang sering terjadi di dalam perusahaan juga menyebabkan karyawan merasa tertekan untuk mengerjakan pekerjaan sesuai dengan yang diinginkan oleh 
pimpinan, namun hasil pekerjaan yang dikerjakan secara tertekan mengakibatkan buruknya kualitas yang didapatkan.

Johnson (1984:261) mengklasifikasikan akibat-akibat industrialisasi yang bersifat negatif terhadap kesejahteraan manusia kedalam 5A, yaitu:

1. Alienation: perasaan keterasingan dari diri, keluarga dan kelompok sosial yang dapat menimbulkan apatis, marah, dan kecemasan.

2. Alcoholism atau Addiction: ketergantungan terhadap alkohol, obatobat terlarang atau rokok yang dapat menurunkan produktifitas, merusak kesehatan pisik dan psikis, dan kehidupan sosial seseorang.

3. Absenteeism: kemangkiran kerja atau perilaku membolos kerja dikarenakan rendahnya motivasi pekerja, perasaanperasaan malas, tidak berguna, tidak merasa memiliki perusahaan, atau sakit pisik dan psikis lainnya.

4. Accidents: kecelakaan kerja yang diakibatkan oleh menurunnya konsentrasi pekerja atau oleh lemahnya sistem keselamatan dan kesehatan lingkungan kerja.

5. Abuse: bentuk-bentuk perlakuan salah terhadap anak-anak atau pasangan dalam keluarga (istri/suami), seperti memukul dan menghardik secara berlebihan yang ditimbulkan oleh frustrasi, kebosanan dan kelelahan di tempat pekerjaannya.

(http://www.policy.hu/suharto/modul_a/maki ndo_26.htm diakses 09 Mei 2015 pukul 20.54 WIB)

Akibat industrialisasi yang disebutkan oleh Johnson diatas menjadi berbagai macam penyebab terjadinya masalah-masalah yang dimiliki karyawan yang berakibat pada tidak optimalnya hasil kerja. Alienasi disebabkan karyawan dituntut untuk bekerja mengejar target yang sudah ditentukan tanpa memperhatikan lingkungan sosial dimana ia berada. Padahal lingkungan sosial menjadi salah satu sumber agar individu dapat nyaman dan bertukar fikiran. Deadline yang seringkali dibebankan kepada karyawan membuat mereka menjadi apatis terhadap lingkungan sosialnya, menurunkan empati terhadap sesama, egois untuk menang sendiri dan juga menimbulkan kemarahan kepada orang-orang di sekitarnya. Alcoholism dan addiction yang disebabkan karena tekanan yang diberikan karena suatu pekerjaan membuat karyawan mengalihkan fikirannya kepada hal-hal yang dapat membuat dirinya bahagia walaupun sesaat. Pengalihan kepada alkohol dan obatobatan yang menimbulkan kesenangan sesaat membuat mereka terus melakukan hal tersebut dan lama kelamaan menjadi kecanduan. Candu terhadap hal-hal yang terlarang dan berbahaya akan membuat tubuh individu menjadi lemah dan sakit, sehingga menurunkan produktifitas kerja dan menganggu kehidupan sosial. Akibat kecanduan ini juga dapat menimbulkan masalah antar karyawan dengan orang-orang di lingkungannya diakibatkan ketidaksadaran setelah meminum alkohol dan obat-obatan terlarang, baik perkelahian, pencurian maupun pembunuhan.

Absenteeism merupakan kemungkinan karyawan bolos bekerja diakibatkan rasa tidak nyaman dalam bekerja di dalam perusahaan tersebut baik karena merasa tidak berguna, tidak memiliki rasa kepemilikan terhadap perusahaan atau karena rasa tidak nyaman dalam berinteraksi dengan rekan kerja dan atau karna penyakit fisik dan psikis. Antar satu perusahaan dengan perusahaan lainnya memiliki Karyawan yang bolos bekerja akan membuat pekerjaan menjadi tertunda untuk diselesaikan, kuantitas yang didapatkan lebih sedikit dan kualitas yang menjadi berkurang. Accidents yang merupakan kecelakaan kerja diakibatkan karena menurunnya konsentrasi karyawan atau karena kurangnya sistem keselamatan dapat menyebabkan karyawan kehilangan kemampuan fisik maupun psikologis dan juga dapat menyebabkan kehilangan nyawa. Hal ini dapat menyebabkan menurunnya kuantitas dan kualitas produk atau 
jasa yang diberikan oleh perusahaan. Abuse yang disebabkan karena lelah dan bosannya dalam bekerja membuat karyawan ketika berada di rumah melakukan penyiksaan terhadap anggota keluarganya. Anggota keluarganya menjadi tempat pelampiasan dikarenakan sulitnya karyawan menyalurkan emosinya ketika bekerja dan cenderung ditutup-tutupi dan ditekan.

Kelima akibat industrialisasi tersebut juga nantinya akan semakin timbul pada masyarakat yang menjadi karyawan di perusahaan-perusahaan yang pada pasar bebas ASEAN semakin banyak di Indonesia. Persaingan yang semakin ketat baik antar perusahaan yang berakibat pada pemberian pekerjaan yang lebih berat lagi kepada karyawan atau antar satu karyawan dengan karyawan yang lainnya dan juga dengan para pesaing yang mencari pekerjaan akan menimbulkan perasaan teralienasi, kecanduan, absen, kecelakaan kerja ataupun tindakan kekerasan karena tingginya tingkat depresi dan tekanan yang diberikan oleh perusahaan agar dapat bersaing dan tidak kalah dengan perusahaan-perusahaan yang lain.

Pemimpin di dalam perusahaan juga menjadi salah satu sasaran dari praktik intervensi pekerja sosial di bidang industri. Hal ini dikarenakan di dalam perusahaan terdapat tim-tim yang terbagi dan mempunyai fungsi dan peran masing-masing. Tim-tim ini dipimpin oleh ketua tim dan juga dibawah pimpinan-pimpinan yang lebih tinggi lagi. Kondisi tim ditentukan dan diarahkan oleh ketua tim. Interaksi dan cara kerja juga dibawa dan dipengaruhi oleh ketua tim. Ketua tim memegan peranan penting dalam membentuk kondisi kerja para karyawannya. Ketua tim yang mudah marah dan hanya mengejar target saja akan membuat kondisi di dalam tim terus menerus tegang dan membuat anggota timnya tertekan, hal ini dapat menyebabkan kelima dampak yang dijelaskan oleh Johnson diatas muncul. Sedangkan tim yang dapat membawa suasana nyaman dalam bekerja dan berinteraksi dapat menimbulkan rasa senang untuk bekerja bagi anggota tim, yang nantinya juga akan menimbulkan hasil pekerjaan yang baik pula.

Kinerja pemimpin di dalam perusahaan juga harus memperhatikan cara dan metode dalam membangun suasana kerja dan mengerjakan pekerjaan bersama dengan anggota timnya. Terdapat teori manajemen 2.0 yang menerangkan tentang manajemen suatu tim yang dilakukan oleh ketua tim dan anggota tim untuk meningkatkan rasa nyaman di dalam tim dengan memperhatikan interaksi satu sama lain dan lebih bersifat humanis. Poin-poinnya antara lain :
1. Menghilangkan ketakutan
2. Meningkatkan kepercayaan
3. Mengurangi kontrol
4. Mengurangi lapisan struktur organisasi
5. Siklus perencanaan makin pendek
6. Humanisasi bahasa dan praktik bisnis

Manajemen 2.0 memandang bahwa karyawan adalah sosok yang positif dan kebanyakan waktu karyawan digunakan untuk melakukan hal-hal yang terbaik. Pandangan ini menjadi landasan bahwa karyawan patut diperlakukan secara lebih manusiawi dan dihargai serta diberikan kepercayaan untuk melakukan tugasnya. Manusia dianggap subyek dalam melakukan pekerjaan dan asset penting bagi perusahaan. Pimpinan dalam perusahaan memperlakukan anggotanya secara manusiawi baik dari segi bahasa, perintah untuk melakukan pekerjaan, kelalaian yang dilakukan oleh anggota tim, kurangnya kepercayaan terhadap anggota tim dan lain sebagainya untuk meningkatkan rasa penghargaan diri karyawan dalam melakukan pekerjaan dan kenyamanan bekerja dalam satu tim dengan anggota lainnya. Peningkatan rasa percaya diri dan kenyamanan dalam bekerja akan meningkatkan produktifitas kerja karyawan untuk menghasilkan produk dan jasa yang berkualitas.

Pekerja sosial industri dapat mengevaluasi kinerja ketua tim dan pimpinan-pimpinan lain 
di dalam perusahaan yang sekiranya tidak memperlakukan karyawan secara manusiawi. Selain dikarenakan karyawan juga manusia yang mempunyai hak untuk dihargai dan dihormati, perlakuan tidak manusiawi akan membuat karyawan tertekan dan kemudian akan berpengaruh terhadap produktifitas kerja karyawan.

Selain masalah-masalah yang terjadi di lingkungan internal perusahaan, lingkungan eksternal perusahaan dari seluruh karyawan juga akan mempengaruhi terhadap kinerja yang dilakukan di dalam perusahaan. Hal ini dikarenakan setiap individu merupakan satu kesatuan sistem yang holistik yang terbentuk dari aspek biologis, psikologis dan sosialnya yang saling mempengaruhi. Jika terdapat gangguan yang dialami oleh karyawan maka akan dapat menganggu konsentrasi dan kualitas kerjanya.

Pasar bebas ASEAN menimbulkan perubahan sosial bagi Negara-negara yang ada di kawasan ASEAN dan juga global, termasuk di Indonesia. Persaingan yang ketat menimbulkan banyak tekanan dari segi ekonomi, sosial, kesehatan, gaya hidup dan lain sebagainya. Hal ini berdampak positif dan negatif bagi masyarakat Indonesia. Dampak negatif yang didapatkan akan berpengaruh terhadap kinerja seseorang sebagai karyawan dalam sebuah perasaaan. Seperti hutang yang membengkak yang terjadi akibat biaya hidup tinggi sedangkan pendapatan yang diterima tidak mencukupi, atau gaya hidup yang mengarah pada minum-minuman dan obatobatan terlarang, perceraian, tindakan kriminal, sulitnya mendapatkan akses untuk mendapatkan kesehatan dan pendidikan bagi anaknya, dan lain sebagainya berpengaruh terhadap kinerja karyawan untuk melakukan sebuah pekerjaan. Kondisi fisik dan psikologis yang sedang sakit juga berpengaruh terhadap menurunnya produktifitas kerja, baik secara kuantitas jam bekerja ataupun kualitas dalam mengerjakan pekerjaan. Kondisi biopsikososial yang terganggu dikarenakan terjadi masalah di luar lingkungan perusahaan dapat berpengaruh terhadap menurunnya konsentrasi kerja, sulitnya berfikir dan bertindak secara efisien dan efektif serta sulitnya bekerjasama dan berinteraksi dengan rekan kerja.

Sasaran lain dari pekerja sosial di bidang industri adalah masyarakat lokal tempat perusahaan berada. Perusahaan 'wajib' untuk menjalin hubungan hubungan baik dengan masyarakat lokal. Selain dikarenakan faktor sosial atau tanggungjawab perusahaan terhadap masyarakat yang 'ditumpangi' oleh perusahaan juga karena untuk menjaga keberlangsungan sebuah perusahaan dapat diterima di kawasan tersebut. Banyak perusahaan yang diusir dan dihancurkan oleh masyarakat karena sebelumnya tidak dapat menjaga hubungan baik dan cenderung merugikan masyarakat, baik secara jangka pendek dan jangka panjang seperti pencemaran lingkungan dan bahan-bahan beracun yang berakibat pada munculnya penyakit ringan maupun berat. Pekerja sosial industri bekerja tidak hanya mengurusi bagian internal, melainkan juga eksternal. Hal ini menandakan bahwa pekerja sosial di bidang industri mempunyai pekerjaan yang lebih kompleks daripada bidang corporate social responsibility atau human resources development.

Pasar bebas ASEAN juga menuntut perusahaan mempunyai hubungan yang baik dengan masyarakat dan juga memperdulikan kondisi masyarakat setempat. Persaingan yang ketat memaksa perusahaan untuk tetap bertahan dalam mengeluarkan produk dan hal tersebut membutuhkan lokasi yang sesuai dan strategis. Ini dapat dilakukan jika terdapat kesinambungan dan saling menguntungkan antara kedua belah pihak. Terlebih lagi pasar bebas ASEAN dapat meningkatkan kesenjangan sosial antara orang-orang yang mempunyai modal banyak dengan masyarakat yang tertinggal. Keadaan ini membuat masyarakat semakin buruk kesejahteraannya. Masyarakat kemudian akan memaksa perusahaan yang berada di kawasannya untuk memberikan manfaat yang setara. Jika tidak, maka perusahaan akan dipandang buruk dan 
akan dipersulit oleh masyarakat untuk melakukan suatu pekerjaan.

Tren saat ini menunjukkan perusahaan tidak hanya memperhatikan bisnis saja melainkan juga kepedulian terhadap sosialnya. Hal ini berkaitan dengan dukungan perusahaan terhadap pembangunan berkelanjutan di masa depan. Citra perusahaan bagi perusahaan lain dan masyarakat sebagai konsumen juga dapat dilihat dari tindakan sosial perusahaan, bukan hanya kualitas produk yang bagus.

Dalam melakukan intervensi praktik, pekerja sosial dapat menggunakan kelima metode dalam pekerjaan sosial. Kelima metode tersebut ialah :

\section{Bimbingan Sosial Perseorangan}

Bimbingan sosial perseorangan dapat dilakukan oleh pekerja sosial terhadap karyawan-karyawan yang memiliki masalah tertentu yang berpengaruh terhadap kinerjanya dalam melakukan suatu pekerjaan atau juga untuk mengembangkan dirinya. Bimbingan sosial perseorangan dapat berupa bidangbidang yang bersifat penyembuhan (problem solving) dan konseling (therapy) yang diberikan oleh pekerja sosial terhadap karyawan yang mempunyai masalah ataupun bidang pengembangan diri (personal development) yaitu bagi orang-orang yang tidak mempunyai masalah namun ingin mengembangkan dirinya, baik dalam aspek keilmuan, keahlian maupun sikap yang dapat dimanfaatkan untuk melakukan pekerjaan.

Masalah-masalah yang dihadapi oleh karyawan dapat yang berasal dari lingkungan internal seperti sulitnya bekerjasama dengan rekan kerja, sulitnya mengerjakan pekerjaan yang diberikan, mutasi, terkena pemutusan hubungan kerja, dan lain sebagainya. Sedangkan masalah yang berasal dari lingkungan eksternal seperti masalah dalam pernikahan, mempunyai masalah kesehatan fisik ataupun psikologis, ketergantungan terhadap minuman dan obat-obatan terlarang, kesulitan dalam menyekolahkan anak, dan lain sebagainya yang berpengaruh terhadap kondisi biopsikososial karyawan.

Masalah-masalah yang dibiarkan akan mempengaruhi kondisi karyawan tidak hanya pada saat itu juga, tetapi juga secara jangka panjang, karena masalah tersebut dapat berpengaruh terhadap aspek-aspek lain di dalam kehidupannya, seperti karyawan yang mempunyai hutang kepada rentenir yang tidak dapat dibayar akan menyebabkan karyawan menjadi miskin dan kehilangan harta benda. Hal ini tidak hanya berpengaruh terhadap menurunnya produktifitas pada saat ini tetapi juga menyebabkan di masa depan kebutuhan dasar karyawan dan keluarganya tidak terpenuhi. Kebutuhan dasar yang tidak dapat tepenuhi berpengaruh terhadap kondisi fisik, psikologis dan sosial yang lebih kompleks lagi dan lebih menurunkan kinerja karyawan.

Dalam bimbingan sosial perseorangan, pekerja sosial dapat membantu karyawan untuk menyelesaikan masalahnya, baik melalui terapi, memberikan informasi, atau menyambungkan sumber-sumber yang diperlukan oleh karyawan untuk menyelesaikan masalahnya. Dalam melakukan intervensi, pekerja sosial terlebih dahulu melakukan assessment.

Assessment adalah tahap pertama dari proses penyelesaian masalah. Termasuk di dalamnya adalah, mendapatkan pemahaman tentang masalah tersebut, apa yang menyebabkannya, dan apa yang bisa diubah untuk meminimalisasi dan menyelesaikannya (Barker, 1987 dalam Budhi Wibawa dkk, 2010:97)

Assesment berguna agar pekerja sosial dan karyawan mengetahui kedudukan masalah, hal-hal yang menyebabkannya, dampaknya sampai sejauh ini sehingga dari penyebab, kedudukan masalah dan dampaknya dapat dicari solusi untuk mengubah atau meminimalisasikan masalah tersebut. Assessment dapat dilakukan melalui metode wawancara dan juga observasi yang dilakukan oleh pekerja sosial, baik selama bekerja di dalam perusahaan maupun di luar perusahaan. 
Pencarian solusi dari masalah tidak hanya dilihat dari satu aspek saja, menlainkan juga dari aspek-aspek lain yang kemungkinan mempengaruhi dan dari sistem yang lebih luas yang berpengaruh terhadap masalah tersebut.

Assessment juga dapat dilakukan untuk mencari tau lebih dalam mengenai dampak negatif yang diciptakan oleh perusahaan terhadap karyawan. Seperti gas-gas beracun hasil kimiawi yang mempengaruhi terhadap kesehatan karyawan atau produktifitas kerja karyawan, sanitasi lingkungan yang buruk atau limbah beracun yang masuk ke dalam air yang digunakan karyawan untuk dipakai dalam kehidupan sehari-hari. Sehingga perusahaan dapat melakukan tindakan-tindakan untuk mengurangi atau menghilangkan dampak negatif yang dihasilkan oleh perusahaan dan juga mengindentifikasi serta mengurangi biaya sosial yang seharusnya dikeluarkan untuk membiayai kerugian yang dialami oleh karyawan karena dampak negatif yang diciptakan perusahaan.

\section{Bimbingan Sosial Perkelompok}

Bimbingan sosial perkelompok adalah suatu metode untuk bekerja dengan, dan menghadapi orang-orang di dalam suatu kelompok, guna peningkatan kemampuan untuk melaksanakan fungsi sosial; serta guna pencapaian tujuantujuan yang secara sosial dianggap baik (Soetarso, Pengantar Kesejahteraan Sosial, 1976, hlm, 72 dalam Budhi Wibawa dkk, 2010 :99)

Manusia dalam kehidupannya tidak hidup sendiri melainkan hidup dalam kelompok. Di dalam kelompok manusia dapat menemukan sumber-sumber yang dibutuhkannya namun tidak dapat dipenuhi oleh dirinya sendiri. Selain itu di dalam kelompok, manusia dapat saling bertukar fikiran dan saling memberikan informasi yang dibutuhkan satu sama lain. Di dalam kelompok juga, prilaku di dalam anggotanya dapat saling menular, prilaku positif dapat mempengaruhi orang lain yang mempunyai prilaku negatif untuk berubah menjadi positif.
Atas landasan tersebut, kelompok dapat digunakan sebagai media untuk melakukan intervensi. Di dalam kelompok, masingmasing anggota yang terdiri dari karyawan yang mempunyai masalah dapat saling menceritakan masalahnya, kemudian saling memberi saran, bantuan dan informasi yang dibutuhkan. Karyawan juga merasa mempunyai kawan senasib yang memiliki masalah yang sama sehingga penghargaan dirinya yang menurun dapat meningkat kembali dan satu sama lain saling mendukung untuk pemecahan masalah masing-masing karyawan. Karyawan yang sulit dan tidak mau untuk dilakukan intervensi pekerja sosial dapat berubah fikiran dan prilakunya karena terbawa emosi oleh karyawan-karyawan lain yang mempunyai semangat positif untuk melakukan terapi kelompok dalam membantu memecahkan masalah yang dihadapinya.

Kelompok-kelompok ini dapat dibentuk berdasarkan masalah yang seragam yang sedang dihadapi dan tujuan yang sama yang ingin dicapai oleh seluruh anggota kelompok. Di dalam kelompok yang berorientasi pada pemecahan masalah akan terjadi dinamika kelompok. Hal ini dikarenakan masing-masing anggota mempunyai kepribadian dan kedalaman masalah yang berbeda-beda. Ini dapat membantu untuk meningkatkan semangat anggota untuk mengikuti bimbingan sosial perkelompok dan juga mendapatkan informasi dan saran yang berbeda-beda pula.

\section{Community Organization/ Community Development (COCD)}

COCD berkaitan dengan tanggungjawab sosial perusahaan terhadap masyarakat lokal yang dijadikan kawasan berdirinya perusahaan. Bedirinya perusahaan tanpa memperhatikan masyarakat sekitarnya akan membuat hubungan perusahaan dengan masyarakat kurang baik. Hal ini dikarenakan akan terjadi kesenjangan hubungan antar keduanya atau kecemburuan masyarakat lokal akibat perbedaan kualitas hidup masyarakat dengan karyawan perusahaan padahal mereka tinggal dalam satu kawasan yang sama. Salah satu cara yang dapat dilakukan untuk tanggungjawab 
sosial perusahaan adalah melalui pengembangan masyarakat lokal.

Melalui pengembangan masyarakat, pekerja sosial bersama dengan masyarakat menemukan potensi yang ada namun belum disadari oleh masyarakat untuk dapat dikembangkan atau terdapatnya masalah yang dapat dihilangkan. Pengembangan potensi dengan memunculkan partisipasi masyarakat berguna untuk meningkatkan kemandirian masyarakat untuk memenuhi kebutuhan di dalam masyarakat dan juga individu-individu di dalamnya yang nantinya berpengaruh terhadap peningkatan kesejahteraan masyarakat. Meminimalisasikan atau menghilangkan masalah juga dapat berpengaruh terhadap hilangnya hambatan bagi masyarakat untuk meningkatkan kemampuan masyarakat dalam memenuhi kebutuhan-kebutuhannya, terlebih lagi dalam pemenuhan kebutuhan dasarnya.

Mencari potensi dan masalah yang ada di masyarakat juga dapat dilakukan melalui assessment bersama dengan tokoh masyarakat dan anggota-anggota masyarakat yang dijadikan kelompok tugas. Hasil assessment dapat dijadikan landasan untuk membuat sebuah program yang bertujuan untuk mengembangkan masyarakat secara mandiri menuju kesejahteraan sosial yang didapatkan masyarakat tanpa adanya kesenjangan sosial.

\section{Penelitian Pekerjaan Sosial}

Penelitian pekerjaan sosial dapat dilakukan oleh pekerja sosial untuk menemukan masalah-masalah atau solusi-solusi yang baru yang dapat diterapkan untuk membantu menyelesaikan masalah baik yang berada pada lingkungan internal perusahaan, seperti masalah yang dihadapi karyawan, pimpinan dalam perusahaan, sistem yang mengatur tata kerja dan juga pengembangan sumber daya manusia (karyawan) baik dalam hal keilmuan, keterampilan dan sikap. Juga pada lingkungan eksternal perusahaan, khususnya dalam menjalin hubungan baik dengan masyarakat lokal melalui pengembangan masyarakat yang merupakan wujud dari tanggungjawab sosial terhadap perusahaan.

\section{Administrasi Pekerjaan Sosial}

Administrasi pekerjaan sosial menurut John Kidneigh adalah proses transformasi kebijakan sosial ke dalam pelayanan-pelayanan sosial... (Budhi Wibawa dkk, 2010 : 117). Pekerja sosial dapat bekerja untuk membentuk pelayanan-pelayanan sosial yang dibutuhkan oleh karyawan dan atau masyarakat, guna meningkatkan kompetensi, produktifitas dan atau kepuasan karyawan terhadap perusahaan tempatnya bekerja dan juga untuk memberikan sumber-sumber yang dibutuhkan oleh masyarakat lokal. Pelayanan yang diberikan dapat berupa rumah sakit, institusi pendidikan yang biayanya gratis bagi karyawan dan masyarakat lokal. Dan juga dapat berbentuk pelayanan penitipan anak, perawatan lanjut usia, koperasi, rumah tinggal karyawan, taman rekreasi dan lain sebagainya.

Pelayanan sosial dibentuk untuk memberikan manfaat-manfaat secara langsung bagi masyarakat dan karyawan. Dengan adanya pelayanan sosial, hambatan-hambatan yang dialami karyawan untuk melakukan pekerjaan dapat ditanggulangi sehingga karyawan dapat melakukan pekerjaannya dengan lebih produktif tanpa terbagi-bagi fokusnya dengan fikiran-fikiran yang lain. Seperti misalnya karyawan wanita yang suaminya juga bekerja dan tidak mempunyai uang untuk mempekerjakan perawat anak dan atau tidak mempunyai kerabat yang dapat dimintai pertolongan untuk menitipkan anaknya akan terganggu pekerjaannya dikarenakan juga harus mengurusi masalah anaknya. Dengan adanya pelayanan penitipan anak yang diberikan oleh perusahaan, maka karyawan wanita dapat membawa anaknya ke dalam penitipan tersebut ketika sedang berada pada jam-jam bekerja tanpa mengeluarkan biaya tambahan.

Pembangunan rumah sakit juga berguna untuk memberikan pelayanan sosial berupa perawatan kesehatan dan pengobatan. Karyawan yang tidak mempunyai biaya untuk 
berobat akan membuat dirinya terus menerus dalam keadaan sakit dan membuat produktifitas kerjanya menurun. Dengan adanya rumah sakit yang biayanya gratis dan atau lebih sedikit dibandingkan rumah sakit lain membuat karyawan dapat berobat dan kemudian dapat bekerja kembali secara normal. Masyarakat juga dapat langsung merasakan manfaat dengan adanya rumah sakit yang didirikan perusahaan. Ketika salah satu anggota masyarakat sakit namun sulit mendapatkan akses ke rumah sakit terdekat atau tidak mempunyai biaya untuk berobat, dengan didirikannya rumah sakit yang berada dekat dengan masyarakat, maka akan memudahkan masyarakat untuk mengakses sumber-sumber kesehatan.

Pelayanan sosial yang didirikan bukan untuk meraih keuntungan perusahaan melainkan memberikan akses-akses atau sumber-sumber yang dibutuhkan bagi karyawan agar karyawan tidak terganggu oleh sulitnya mendapatkan sumber-sumber kebutuhan yang berpengaruh terhadap menurunnya produktifitas kerjanya dalam perusahaan. Pelayanan sosial juga bertujuan untuk mewujudkan tanggungjawab sosial perusahaan terhadap masyarakat. Tanggungjawab sosial yang dimaksud adalah memperdulikan kondisi masyarakat dimana perusahaan berada dan melakukan tindakan untuk membantu masyarakat dalam meingkatkan kemampuan lokal dan kesejahteraan masyarakatnya.

\section{SIMPULAN}

Berdasarkan pembahasan yang sudah dipaparkan sebelumnya, kesimpulan yang dapat ditarik adalah pekerja sosial di bidang industri dalam menghadapi pasar bebas ASEAN mempunyai peranan yang sangat penting. Hal ini dikarenakan pasar bebas ASEAN akan meningkatkan kompetensi perusahaan untuk mengembangkan jangkauan pasarnya dan meningkatkan kualitas produk dan jasanya agar tidak kalah dengan para pesainya. Termasuk juga di Indonesia, perusahaan-perusahaan nasional maupun yang berasal dari luar akan berkompetensi untuk membangun perusahaan di Indonesia dikarenakan sumber daya manusia yang banyak dan sumber daya alamnya yang melimpah. Namun, sumber daya manusia yang melimpah yang kemudian dapat direkrut untuk menjadi karyawan tidak akan dapat meningkatkan kualitas produk dan jasa jika sumber daya manusianya tidak diperhatikan kondisi biopsikososial dan tidak ditingkatkan kompetensinya.

Pekerja sosial industri dengan kemampuan yang dimilikinya untuk memodifikasi perilaku dapat menjadi salah satu profesi yang bekerja di perusahaan untuk meningkatkan produktifitas kerja karyawan baik dengan cara memperhatikan kondisi biopsikososialnya maupun dengan cara meningkatkan kompetensi karyawan.

Produktifitas kerja karyawan dapat menurun dikarenakan terdapat masalah baik yang ada di lingkungan internal perusahaan maupun lingkungan eksternal perusahaan. Pekerja sosial dapat membantu karyawan untuk menyelesaikan masalahnya melalui metode bimbingan sosial perseorangan, bimbingan sosial kelompok atau memberikan pelayanan sosial yang dibutuhkan oleh karyawannya. Metode ini digunakan untuk membantu karyawan menemukan solusi atau sumbersumber yang dapat digunakan untuk menyelesaikan masalahnya sehingga dapat meningkatkan produktifitas kerjanya.

Pekerja sosial juga berurusan untuk berhubungan dengan lingkungan eksternal perusahaan yaitu masyarakat setempat. Hal ini berkaitan dengan tanggungjawab sosial perusahaan dan menjalin hubungan baik dengan masyarakat setempat demi keberlangsungan perusahaan. Metode yang dapat digunakan adalah melalui community development dan juga pelayanan sosial bagi masyarakat. Community development digunakan untuk meningkatkan partisipasi masyarakat untuk meningkatkan kesejahteraan masyarakatnya melalui potensi dan pencegahan masalah serta pemanfaatan lembaga-lembaga yang ada. Pembangunan 
pelayanan sosial bagi masyarakat juga berguna untuk memberikan sumber-sumber yang tidak dapat dipenuhi oleh masyarakat sendiri, seperti lembaga kesehatan ataupun pendidikan.

\section{SARAN}

Pekerja sosial yang merupakan lulusan dari ilmu kesejahteraan sosial sudah harus mulai menekuni pada bidang industri. Meskipun pekerja sosial di bidang industri tidak secara langsung mengurusi masalah sosial yang terjadi, namun sumber daya manusia yang ada dalam perusahaan juga harus diperhatikan. Hal ini dikarenakan juga akan berdampak pada kesejahteraan manusia. Kualitas sumber daya manusia yang rendah akan membuat mudahnya pemutusan hubungan kerja yang dilakukan oleh perusahaan dan kemudian akan menimbulkan bertambahnya masalah sosial, seperti pengangguran dan tindakan kriminal. Tekanan atau depresi yang dialami oleh karyawan akibat faktor internal dan eksternal perusahaan juga akan menghambat produktifitas karyawan dalam bekerja. Terlebih lagi ketika memasuki pasar bebas ASEAN yang kompetensi antar pesaingnya semakin banyak, tidak hanya antar warga Negara lokal saja tetapi juga dengan Negara-negara yang lain. Tidak menutup kemungkinan perusahaan juga semakin tidak memperhatikan hak-hak manusiawi karyawan dikarenakan tuntutan pasar untuk semakin bersaing.

Memperhatikan kebutuhan dan hakhak karyawan sebagai manusia juga bukan hanya dikarenakan untuk meningkatkan finansial perusahaan tetapi juga berkaitan dengan keadilan sosial dan pemberlakuan hakhak yang setara pada semua orang tanpa memperhatikan jabatan. Hal ini juga menjadi alasan pekerja sosial juga harus turut mengambil peran dalam bidang industri.

Pendidikan dalam ilmu kesejahteraan juga seharusnya sudah semakin fokus dalam mendidik calon pekerja sosial untuk terampil dalam mengaplikasikan keilmuan, keterampilan dan nilai-nilai yang didapatkannya untuk dapat diterapkan dalam dunia industri dan melakukan intervensi pekerjaan sosial terhadap karyawan, pimpinan dalam perusahaan dan masyarakat setempat, termasuk didalamnya mengidentifikasi kebutuhan-kebutuhan dan masalah-masalah yang berdampak negatif bagi karyawan, perusahaan dan masyarakat setempat sehingga dapat diambil tindakan sesegera mungkin untuk mencegah timbulnya kerugian dan biaya sosial yang harus dikeluarkan perusahaan untuk menanggulangi kerugian yang telah dibuat.

Pemerintah sebagai pemegang kebijakan juga dapat memegang peranan untuk mengarahkan perusahaan-perusahaan yang ada di Indonesia untuk memperhatikan sumber daya manusianya (karyawan di dalam perusahaan) dan tanggungjawab sosial terhadap perusahaan melalui intervensi pekerjaan sosial yang dilakukan oleh pekerja sosial yang mempunyai metode-metode tertentu untuk meningkatkan keberfungsian sosial karyawan agar dapat menjalankan perannya sesuai status yang diberikan oleh perusahaan dan juga meningkatkan kesejahteraan masyarakat setempat melalui metode pengembangan masyarakat.

\section{DAFTAR PUSTAKA}

Bancar, Bocah. "Pekerjaan Sosial Industri". Melaluic

https://bocahbancar.files.wordpress.c om/.../pekerjaan-sosial-industri.doc [2015/05/10]

Berita satu. "60 Juta Penduduk Usia Porduktif Jadi Modal Indonesia" Melalui http://www.beritasatu.com/ekon omi/248255-60-juta-pendudukusia-produktif-jadi-modalindonesia.html [2015/05/10]

Costik, mail. 2014. "Pengertian Pasar Bebas Ekonomi Asean". Melalui http://mailchaozkhakycostikcomunity.blog spot.com/2014/10/pengertianpasar-bebas-ekonomiasean.html [2015/05/10] 
Raharjo, Santoso Tri.2010. "Pekerjaan Sosial dalam Bisnis dan Industri”. Melalui http://kesos.unpad.ac.id/?p=480 [2015/05/09]

Suharto, Edi. "Pekerjaan Sosial Industri". Melalui http://www.policy.hu/suharto/modul _a/makindo_26.htm [2015/05/09]
Wibawa, Budhi dkk. 2010. Dasar-dasar

Pekerjaan Sosial. Bandung : Widya Padjajaran

Wibowo, Hery. "Manajemen 2.0". Melalui Mata Kuliah Semester 6, Manajemen Lembaga Pelayanan Sosial 